・書物を刊行しなければならず，学術の動向に応じた体制を整えなければならない，このため，ときに は dirty な Business が生れ，誰かがその衝に当らなければならない。

他方, 結晶学がともすると万余の物質を機械的に扱 らにとどまり, 物理・化学・生物学等の基礎学へ の寄与が稀薄となったり，逆にそれらからの栄養吸収を怠るならば結晶学自体が衰微する。このことは， 結晶成長・鉱物学・薬学・金属学・半導体工学等々の応用方面との関連を考える上でも同じである.こ の点はIUCr の大きな関心事で, 同じことは結晶学研究所に関連して我が国でも論ぜられた.

すべての問題を一々挙げるわけには行かないが，IUCr が当面しているいくつかの問題に触れる．以 前から，|F|-Table を Acta から除くべきか？ Structure Report の発刊の遅れをどらするか？さら に, Report そのものの意義があるかの問題が提起されている，|F|-Table については一応の解決を見 て, 既に Acta に方針が打ち出されていることは周知のことと思ら。これらの問題は Computer の発達 に伴ら DATA 保存の現代的課題でもある. 今回, 何人かの委員に依頼し長期的方策を考えてもららこ とになった。 日本からも桜井さんが委員となっているので御意見のある方は御連絡戴きたい.日本の中 でも早晚何らかの手を打たなければならないであろら．また国際的にいくつかの DATA 処理センター が出来た折には，アジア地域で日本にセンターを作る責務があるのではなからうか.

諸科学との関連のため，今回，三年の期限付きで charge, spin, momentum 分布に関する新しい commission が作られた．結晶学と物理学との結びつきの上で結構なことと思う。このような Actionを 行なら場台，米国勢力の伸長であるとか他の分野で同じょらに commission が要望されたらきりが無い といら次元の低い議論が出るのは洋の東西を問わ妨ことである. 大局的に見て戴きたいと思5.1973年 フランス・ボルドーで結晶学ヨーロッパ会議が開かれる. IUCrは $\$ 750$ の支持を与える. 1974 年日本 で開かれる結晶成長会議及びスクールにも合計 $\$ 2,000$ の支援をすることとなった．関連分野との緊密 化を進めるためである．また，同年オーストラリアで回折結晶学を中心テーマとする会が開かれるが $\$ 2,000$ 程度の補助をする.これらの Action は，三年置きの大きな会合の間に特殊テーマによる学術 会議を振興するためでもある. 大きな Congress の存在意義について，各方面でも論ぜられているが， 当分は小さい会と二本立てで, 大きな会の膨張を抑制するのが妥当な解ではなかららか.

\title{
Business と年龄
}

紙数が足りなくなったので, $2 \sim 3$ の事例を挙げ結論を述べたい，今回，IUCr の general secretary および Treasurer の Cruickshank（1924）に代り Denmark の Rasmussen (1925) が任命された。 ま た, J. Appl. Crystallography の co-editor として Rooksby (1906) に代り Bristol の Hart (1938) が 任命された. IUCr として重要な commission である Structure Report及び International Crystal Table の chairmanにはそれぞれ Trotter (1933) および Hahn（1928）がなった。（）は生年である．今 回, 結研連委員はかなり若返ったが，選挙された12名は1926年生れより年輩の方のみであった．結晶学 関係者が絶えず Business に当たる人の若返りを心掛けると共に，年令構成にも配慮する必要があろら.
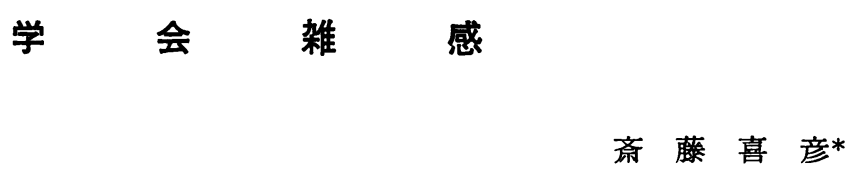

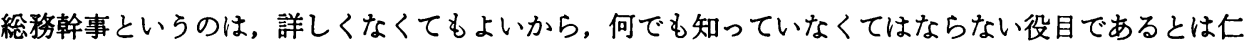
田先生の言であった. 実際のところ組織委員長の三宅先生は, 細かいところまでよく気のつく方で, 種 々なことを進んでおやり下さったし，傘下の各小委員長がこれまた役者揃いであったので，総務幹事は 何もしないでただ右往左往している中に，万事すらすらと運んで，学会は無事に終ってしまったような 気がする．これはひとえに皆様の御努力によるもので，感謝の思いで一杯である.

* 東京大学物性研究所

15. $1-156$ 
私なりに多少とも気を使ったことといえば，何しろ組織委員をはじめ各種の委員を合せると60名以上 といら大世帯であり，各人の性格がすべて違っているので，この人々がそれぞれ気持よく活動できる場 を作るよう努力したといらことであろらか．関西と関東とでは，やはり長い間の習慣やものの考え方が 少しつうつ違っているので，その調整には大阪生れ大阪育ちで関東に10年以上住みついた私などは少しは お役に立ったように思われる。

学会の運営についての苦心談は他の先生方がお書き下さると思うので, 私は他の方があまりお書きに ならないと思われる募金のことについて少し記しておくことにする.

このような国際会議で最も苦心するのは財政である．政府予算には一定の規隼があつて多くは望み得 ないまた一方，参加者からは，国際的な慣例もあり，各人の懐具合を考えるとむやみに参加費を取り 立てるわけにもゆかないので, 結局産業界からの好意ある醕金に待たなければならないといらことにな る.ところがいざとなってみると，結晶学の対象は広範囲ではあるが，産業界とのつながりは決して強 くないまま結晶学者で産業界に対して大きい発言力のある先生方はきわめて少数である.そこへいわ ゆるドル・ショックが起った．会社は財布のひもを強くしめるといらわけで心配な要素ばかり多かった。

募金委員長の代先生，副委員長の茅先生と幹事数名が何度も銀座の茅事務所に集まって相談した。 結局経団連花村専務理事の御意見に従って, 財界の有力者 10 名にお願いして, この国際会議の世話人会 といらものを作っていただき，活動を開始した．最初はこの学会には実際にどのくらいの費用がかかる のか見通しを立てるのが大变であった．募金の認可を得るためには，はっきりした金額を書いておく必 要があり，あとでそれをむやみに变えるわけにもいかない，結局大体の見通しを立てて，カンによって， 少し水增しをして申請をしたのであったが，結果として物価の值上りや思いがけない支出があって大体 収支相償ったので，肩の荷を下した思いである，募金目標を 3,000 万円として，募金委員会が発足した. それから足を棒にして会社まわりが始まる．仁田先生のお伴をして行くときには，まづ二・三日前に地 図をたよりに銀行や会社の場所を下見に行っておく．何しろ生れてまだ一度も行ったことのない会社が 多かったので仕方がない。おかげさまで東京の中心部の地理に大変詳しくなった.

一度では駄目であるから，何度も行かねばならない，一人で行くのは少し心細かった．仁田先生，茅 先生のお伴をしていくときは気が楽である. 両先生の蔭にかくれて，お茶か何かを飲んでおればよいか らである.ところが一人で行くと, 結晶学とは一体何ですかと聞かれる. 相手は大てい総務部の奇付担 当者であり，神社の奉賛会や碁や将棋の団体の会館を建設する寄金の募集とか種々な人物が現われるの を応接しているのであるから無理むない，そこで，自動車のバンバーは鉄でできていますが，これは小 さい結晶の集まったもので，とか何とか話しはじめ(これは実は茅先生の受売りである)，最後はたい てい高血圧の薬や制ガン鼡の話で終ることになる.

最初は我ながら少々怪しかったが，度重なるにつれて段々慣れて大変上手になった。一軒一軒歩いて 行くと，何となく押売りか水道やガス代の集金人になったよらな気がした．それでも，この仕事は私に とってよい修業となった，仁田，茅両先生のお伴をして，財界の有力な人々に直接お目に掛ることがで き，いろいろお話を聞けたのも得難い経験であった．募金の責任者として，一体どのくらい集められる かは心配の種である. どの会社は何万円と絶えず考えていたせいで, 学会終了後, テレビのコマーシャ ルを見ていて，会社の名前が出て来ると，ここは何百万円，ここは何十万円と金額ばかりすぐに頭に浮 んできて閉口した。この原稿を書いている現在では，それほどでもなくなったが。

それはさておいて，佃先生，茅先生をはじめ，募金委員の先生方のおかげで，あの不況下（といっ ても今ではちょっと想像できないかも知れないが）にもかかわらず募金は予想以上に進捗し，学会関係 者から感謝して戴けたのをこの上なく嬉しく感じている．この機会に重ねて，好意ある援助を惜しまれ なかった各会社団体に対して厚く御礼を申上げる次第である. 